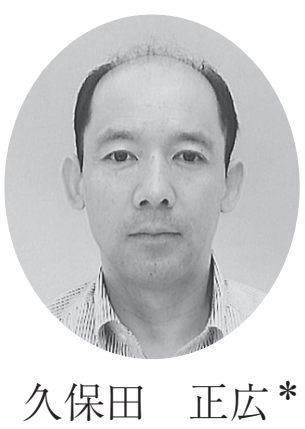

\author{
Journal of The Japan Institute of Light Metals, Vol. 67, No. 6 (2017), 243-250
}

(C) 2017 The Japan Institute of Light Metals

\title{
Enhanced mechanical properties of light metals produced by powder metallurgy
}

Masahiro KUBOTA*

Keywords: mechanical milling; spark plasma sintering; commercially pure aluminum; commercially pure titanium; hardness

\section{1.はじめに}

アルミニウム合金を始めとする軽金属は, 図1に示すよう に一般的に溶解鋳造プロセスで製造されている。そのため, 合金を製造する際に添加する元素の種類やその量は, 平衡状 態図や比重の制約を受けるため, 合金系の種類は限定され ている ${ }^{1), 2)}$ 。これらの合金は, 形状を付与させるプロセスや 熱処理の組み合わせによって適切な組織制御が行われている が, 機械的性質の飛躍的な向上や新たな機能性を付与させる には限界がある。一方で，粉末治金プロセスは，粉末を出発 原料とするため液相を介さないことから平衡状態図に左右さ れない合金設計が可能である。そのため，添加する元素の種 類やその量の選択に大きな自由度があるプロセスとして知ら れている ${ }^{3), 4)}$ 。開発目的や設計要件に併せて出発原料を選択 し，これらを擋拌・混合するプロセスであるメカニカルミリ ング，そして得られた粉末を固化成形する技術として放電プ ラズマ焼結，これらの詳細は後述する。2つを組み合わせた プロセスは，合金設計の自由度を高め，かつ固化成形時に二 アネットシェイプといった形状付与の役割を担っている。

近年, 地球規模で環境問題が顕在化しつつあり, さらに一 次資源の確保やリサイクルといった観点から添加元素の使用 量削減が求められている。また, ユビキタス社会の構築が叫 ばれる今日，高価な添加元素を用いない合金設計の重要性も 高まってきている ${ }^{5)}$ ）。もし仮に合金元素を軽金属に添加 せずに，既存の構造材料と同等もしくはそれ以上の機械的性 質を得ることができれば，リサイクルの推進や省資源化など の観点から環境負荷を大幅に低減できる可能性がある。この ような背景から酸素, 窒素および炭素などの不純物元素, す
なわちユビキタス元素を有効利用することは, 種々の問題の 解決にとって効果的である。

本解説では，まず軽金属の高機能化を実現するためのプロ セスとして粉末治金プロセスを概説し，次にこのプロセスに よって作製された材料特性を紹介する。特に, 面心立方構造 の工業用純アルミニウム（以下, 純アルミニウム）拈よび稠 密六方構造の工業用純チタン（以下, 純チタン) に焦点を絞 り, 合金元素を添加せず，ユビキタス元素を積極的に取り入 れた合金設計やプロセス設計について解説し, 低炭素社会や ユビキタス社会の構築にとって粉末治金プロセスが有効的か

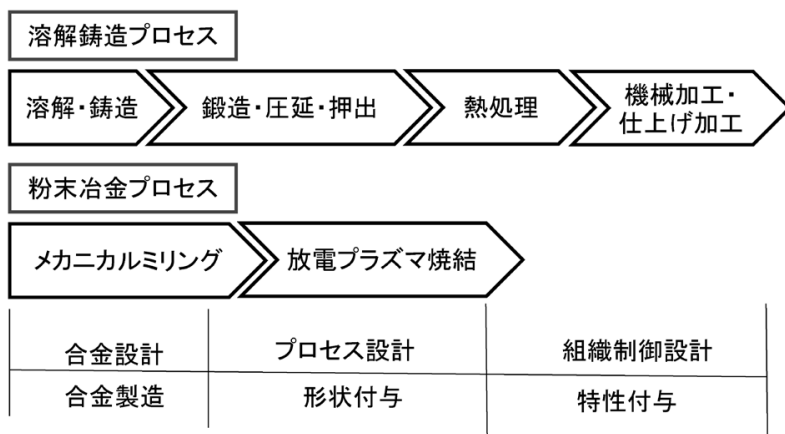

図1 軽金属の製造プロセス; 溶解鋳造プロセスと粉末 治金プロセスの比較

メカニカルミリング処理

\begin{tabular}{|c|c|c|c|}
\hline $\begin{array}{l}\text { 結晶粒微細化 } \\
\text { ホールペッチ則 }\end{array}$ & $\begin{array}{c}\text { 加工硬化 } \\
\text { ひずみ硬化 }\end{array}$ & $\begin{array}{c}\text { 分散強化 } \\
\text { オロワン機構 }\end{array}$ & $\begin{array}{c}\text { 固化 } \\
\text { コットルル効果 }\end{array}$ \\
\hline
\end{tabular}

図2 MM処理から得られる軽金属の強化機構

*日本大学生産工学部機械工学科（干275-8575 千葉県習志野市泉町 1-2-1） Department of Mechanical Engineering, College of Industrial Technology, Nihon University (1-2-1 Izumi-cho, Narashino-shi, Chiba 275-8575) E-mail: kubota.masahiro@nihon-u.ac.jp

受付日：平成29年1月9日＼cjkstart受理日：平成29年3月20日 


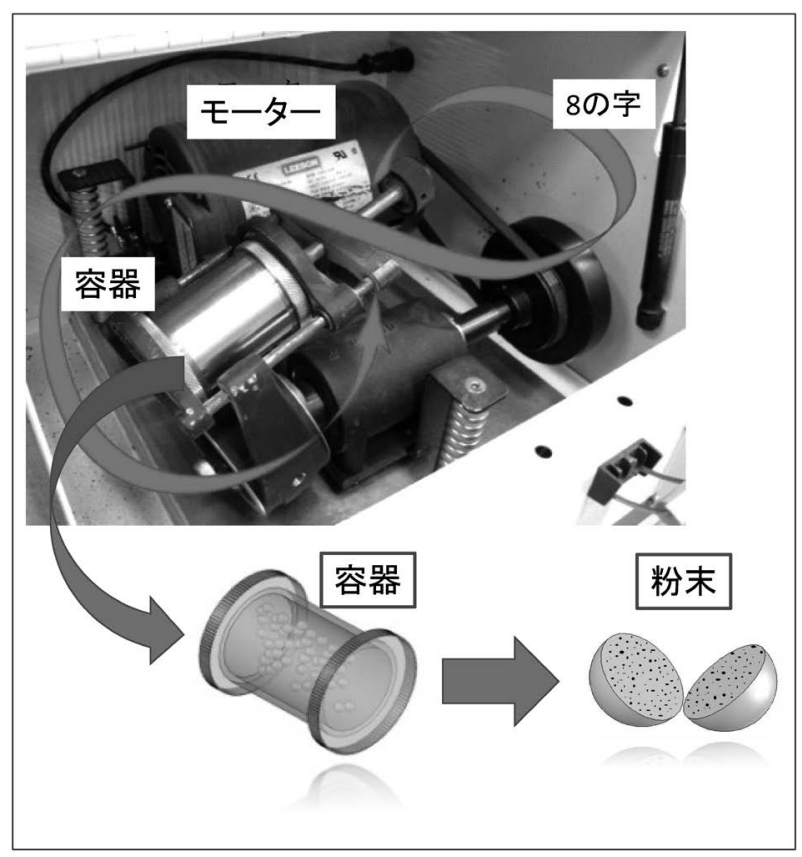

図3 MMプロセスに使用する振動型ボールミル装置の 外観, 容器および粉末の模式図

つ効果的であることを示す。ユビキタス元素と粉末治金プロ セスを組み合わせた革新的な合金設計とプロセス設計によっ て, 軽金属の高機能化が達成され, 適用範囲がさらに拡がる ことを期待する。

\section{2. プロセス設計および合金設計}

\section{1 プロセス設計}

合金元素を添加しないで純アルミニウムや純チタンの強度 レベルを向上させるには，例えば塑性ひずみの導入を図りマ トリックスを加工硬化させる方法やマトリックスの結晶粒径 を微細化する方法が考えられる。一方で, メカニカルミリン グ (Mechanical Milling: MM) プロセスの適用によって図2に 示すような金属材料の強化機構, すなわち結晶粒微細化によ る強化, 加工硬化, 分散強化, 固溶強化を同時に発現させる ことが可能である。粉末加工プロセスの一種である MM と は, 単一金属粉末を容器内で擋汼・混合しながら金属粉末に 変形, 接合, 粉砕の過程を繰り返し与え, 塑性ひずみの導入, 粉末の微細化および組織の均一化を達成することができる手 法である。著者の研究グループで, MMプロセスに使用して いる振動型ボールミルの外観を図3に示す。各種金属粉末と 擋汼ボールを容器内に封入し，それを装置の中央部に設置す る。この容器にはべルト駆動によってモーターから発生した 動力が伝えられ，「8の字」の軌跡をとりながら容器内の金 属粉末が擋拌・混合する。このとき, 粉末には変形, 接合, 破砕が生じる機構になっている。MMプロセスの原型となっ た技術は，1960年代に米国INCO社の J. S. Benjamin らによっ て開発されたメカニカルアロイング (Mechanical Alloying: MA） 法 $^{8)}$ に端を発している。その開発目的は, ガスタービ ン用ニッケル基超合金の高温強度を改善することにあり，酸 化物の微細粒子をマトリックス中にいかに均一に分散させ るかという観点から生れた粉体の複合化プロセスであった。 MA プロセスは，マトリックスと添加する機能性粒子との融

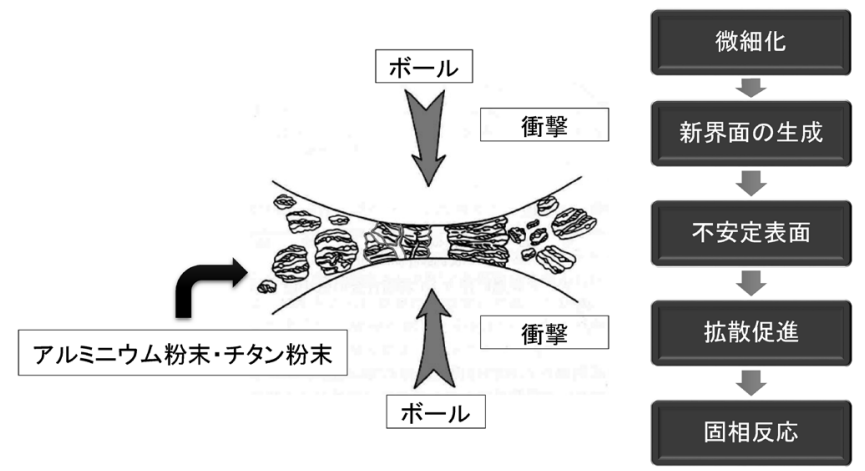

図4 MMプロセス中の粉末とボールの衝突の様子の模 式図ならびにMMプロセスによって得られる効果

点差や密度差を考慮する必要がまったくなく, すべての系に 対して固相状態で適用が可能なため, 溶解鋳造プロセスより も自由度がはるかに高い特徵を有している ${ }^{9) \sim 13)}$

MA プロセスでは, 全体的な粒子が群を形成して大きな移 動を起こす対流混合, 粒子群内の速度差によって粒子が局所 的な移動を起こすせん断混合および個々の粒子の密度差に

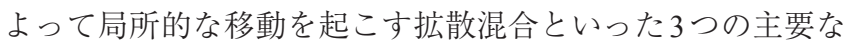
混合形態が同時に起こることが知られている ${ }^{14)}$ 。図4に示す ように例えば，アルミニウム粉末やチタン粉末が擋拌ボール 同士の衝突によってせん断混合が生じ，反応面積の増大およ び拡散距離の短縮が促進される。同時に, 擋找ボールから与 えられる機械的な運動エネルギーの付与により不安定な不規 則粒子へと変態し, 安定になるために拡散混合, すなわち固 相反応が促進される。さらに, 対流混合によりセラミックス のような強化相粒子をマトリックス中に均一かつ微細に分 散させることが可能で, これによって高強度化が達成され る $^{15)}$ 。MMプロセスでも上記で述べた基本的な混合形態がプ ロセス中に金属粉末の内部で生じる。

MM処理によって作製された粉末をバルク化するプロセス として, 一般的な粉末治金法では粉末を金型に充填後, 冷間 圧縮することによって予備成形体を作製し，それらをホット プレスや熱間押出加工によって形状付与する固化成形法が適 用されている ${ }^{3), 4)}$ 。しかし，このような一般的な工法では工 程数が多くなるのと同時にプロセスごとの条件設定が複雑に なり, プロセスコントロールに難点がある。近年, 工程数の 削減かつ短時間で粉末からバルク材への作製が可能な放電プ ラズマ焼結（Spark Plasma Sintering: SPS）プロセスが注目さ れている。当初, SPSはセラミックス粉末の固化成形プロセ スとして, 1990年代の初めに住友石炭鉱業株式会社によっ て開発された ${ }^{16)}$ 。粉末が充填された金型を加熱する従来の 方法ではなく，直流パルス電流を型内部の粉末に直接与える ことによって粉末間に放電現象を起こさせ粉末表面に形成さ れている酸化皮膜を除去し, さらに発生するジュール熱と上 下のパンチから与える圧力によって粒子間接合を行い, バル ク材を作製する方法である。粉末試料内部からの自己発熱作 用を利用し, 従来のホットプレス法や熱間静水圧法よりも低 温域かつ短時間で焼結あるいは接合を可能にしている ${ }^{17)} 。$

図 5 にPSプロセスで使用するパンチ, 黒鉛型および粉末 の配置図を示す。MM処理によって創製された高機能性を有 する粉末を黒鉛型に充填後, 上下パンチによって圧力を加 

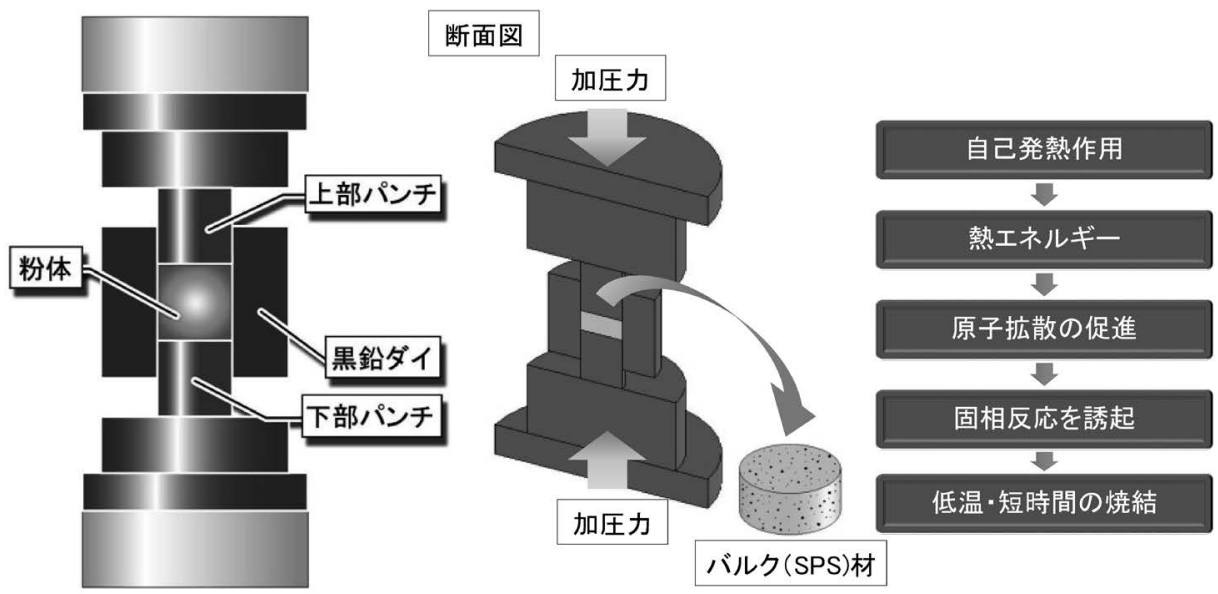

図 5 SPS プロセスで使用する黒鉛型とパンチの模式図およびSPSから得られる効果

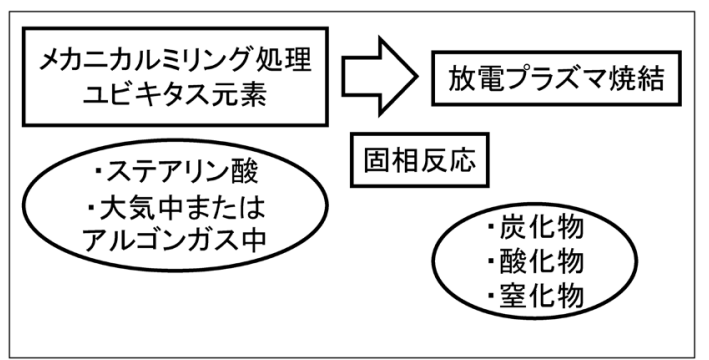

図6ユビキタス元素を伴ったMMプロセスとSPSに よって誘起される固相反応生成物による軽金属の 高機能化

え, 同時に通電加熱しながら焼結する。この固化成形手法を MMプロセスで得られた純アルミニウムや純チタン粉末の固 化成形に適用すれば, 純アルミニウムや純チタン表面に形成 されている酸化被膜の破壊を可能にし， かつ低温，短時間の 焼結によって，MM処理によって創製されたこれらの金属粉 末が有する微細な結晶粒組織や分散粒子を粗大化させること なく焼結できる ${ }^{18)}$, 19)。

\section{2 合金設計}

高価な合金元素を添加せずに純アルミニウムや純チタン の強度レベルを向上させる合金設計の基本概念として, MM 処理中に金属粉末の過度な凝着や接合を防ぐために添加 するミリング助剤 (Process Control Agent: PCA) に着目し た。一般的なPCAとして, 安価で低融点の固体高分子有機 物が使用されており，著者の研究グループでは純アルミニ ウム粉末 $\left.\left.{ }^{18)}, 20\right), 21\right)$ または純チタン粉末 $\left.{ }^{19)}, 22\right)$ にステアリン 酸 $\left(\mathrm{CH}_{3}\left(\mathrm{CH}_{2}\right){ }_{16} \mathrm{COOH}\right)$ を添加している。これらの粉末に対 して MM処理した結果，潤滑剤としての効果によって，それ ぞれの粉末の回収量はほぼ100\%になることが実験的に明ら かにされている。PCAの添加量は， $\mathrm{MM}$ 処理の時間が短い時 は少なく，処理時間が長くなるにつれてその量を増やす必要 があることが経験的に明らかにされている ${ }^{23)}$ 。

PCA 添加の2つ目の役割は, 図6に示すようにMM処理中 にPCAを構成するユビキタス元素をマトリックス中に取り 込み, 固相状態で反応が誘起させる状態を創り出すことにあ る。言い換えれば，粉末はMM処理によって撹挥ボールに よる衝突によってせん断作用が働き微細化され，かつ反応面
積が増大し, さらに拡散距離の短縮が達成される。このた め, 得られる粉末は固相反応が誘起されやすい状態になって いる。このとき, 粉末には機械的な運動エネルギーの付与に より格子欠陥の塑性ひずみが蓄積され, 熱力学的に不安定な 不規則粒子へと変態しているため, このエネルギーが駆動力 となり固相反応が誘起される ${ }^{24)}$ 。例えば, MA処理によって 添加する酸化物粒子がマトリックス中で熱力学的に不安定な 場合, 添加された酸化物は分解して酸素を放出し, 熱力学的 により安定な酸化物が代わって生成される $\left.{ }^{25)} 28\right) 。 一$ 方で, PCAを添加したMM処理では粉末の内部にPCAの構成元素 が取り込まれ, 非平衡状態となっている。粉末作製の段階で は, 固相反応が誘起されない場合も認められており, また SPS プロセス中の加熱によって固相反応が誘起される場合も ある。これらの律速過程は, MM処理によって粉末に導入さ れる駆動力の大きさ，すなわち機械的な運動エネルギーの大 きさや粉末の表面状態に大きく依存する。いずれにせよ，転 位の移動はこれらの固相反応によって生成される粒子, すな わちin-situ生成による微細な粒子によって妨げられ，いわゆ るオロワン機構のメカニズムによって材料の高強度化はもた らされる。

PCAを伴ったMM-SPS プロセスによって誘起される固相 反応過程は, 純アルミニウムや純チタンで以下に示す反応式 として表すことができる。

純アルミニウム : $\mathrm{Al}+\mathrm{C}_{17} \mathrm{H}_{35} \mathrm{COOH} \rightarrow \mathrm{Al}+\mathrm{Al}_{4} \mathrm{C}_{3}+\gamma-\mathrm{Al}_{2} \mathrm{O}_{3}$ 純チタン : $\mathrm{Ti}+\mathrm{C}_{17} \mathrm{H}_{35} \mathrm{COOH} \rightarrow \mathrm{Ti}+\mathrm{TiH}_{2}+\mathrm{TiC}+\mathrm{TiO}_{2}$

これらの固相反応過程は, 熱力学的な標準生成自由工 ネルギーの計算から理論的に推定でき,さらに最も安 定な系が生成することが実験的にも明らかにされてい

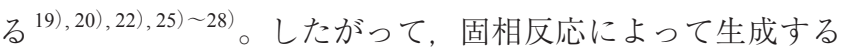
化合物相を検討した両者には，一般的によい一致が認められ ている。また，固相反応によって生成するこれらの金属間化 合物は, 強化相として機械的性質の向上に効果的に寄与する と考えられる。

\section{3. 材 料 特 性}

\section{1 純アルミニウムに対するMM-SPS プロセスの適用}

MM処理によって作製された粉末の硬さ ${ }^{21)}$ とそれらの粉 末をSPS装置によってバルク化した材料の硬さを図 $7^{28)}$ に示 


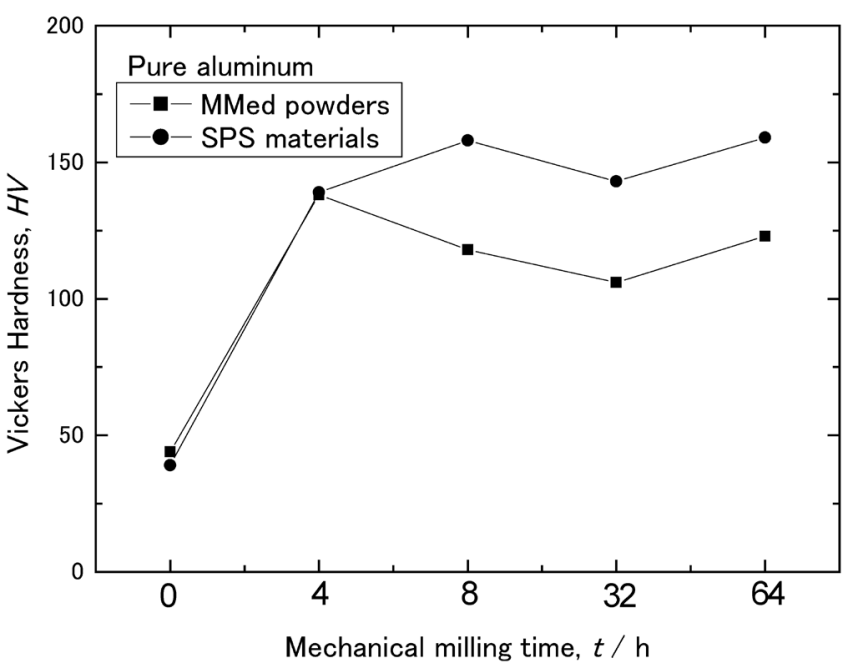

図7 純アルミニウム粉末にMM処理して得られた粉末 の硬さとそれらをSPS装置で焼結して得られたバ ルク材の硬さの比較 ${ }^{28}$

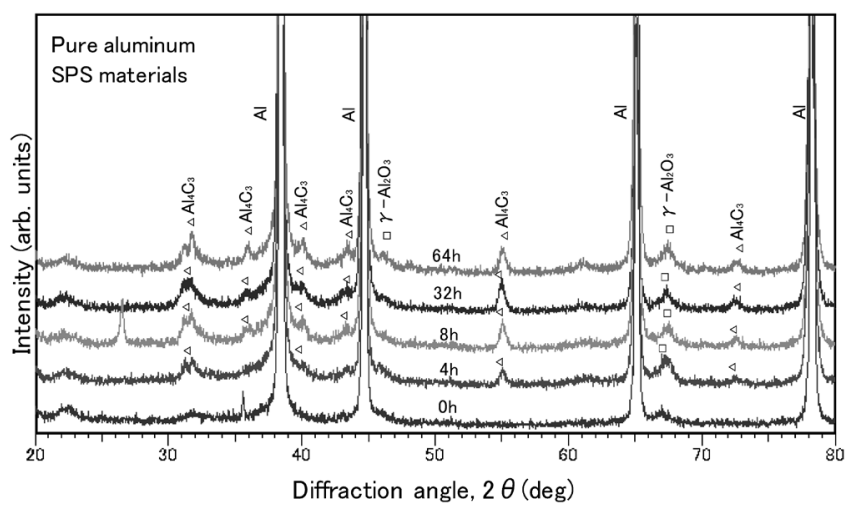

図8 純アルミニウム粉末にステアリン酸を添加して MM処理して作製した粉末から得られたバルク材 のX線回折パターン28)

す。MM処理をしていない純アルミニウム粉末から作製した バルク材の硬さは39HVを示し, MM 4hの粉末をバルク化 すると $139 \mathrm{HV}$ まで硬度レベルが高められた。MM $64 \mathrm{~h} の$ 粉 末から作製したバルク材の硬さは, 最も高い值 $159 \mathrm{HV}$ を示 した。各バルク材の硬さは, MM粉末の硬さとほぼ同程度か らわずかに高い值を示したことから，MM粉末の特性を損な わずにSPSによる固化成形が達成されていることが示唆され た。

各MM時間によって得られた粉末から作製したバルク材 の化合物相をX線回折によって同定した結果を図 $8^{28)}$ に示 す。各バルク材のプロファイルにはアルミニウム以外の回折 ピークが認められ，それらは $\gamma-\mathrm{Al}_{2} \mathrm{O}_{3}{ }^{29)}$ および $\mathrm{Al}_{4} \mathrm{C}_{3}{ }^{30)}$ と同 定された。MM4hから得られた粉末を $873 \mathrm{~K} て ゙ 24 \mathrm{~h}$ 加熱して も $\mathrm{Al}_{4} \mathrm{C}_{3}$ の生成は認められなかったが，作製したままのバル ク材では $\mathrm{Al}_{4} \mathrm{C}_{3}$ の生成が認められた。この結果から, SPS 中 に加わる圧力によって MM粉末の粒子間距離，すなわち拡 散距離が短くなり，粉末同士がネックを形成し粒子間結合す る際，固相反応が誘起されたと考えられる。したがって，固 相反応を誘起させるにはまずMM処理によって熱力学的に 非平衡状態を創り出すことが必要条件で，その粉末に対して 加熱は必須だが，同時に圧力を負荷することが十分条件とし

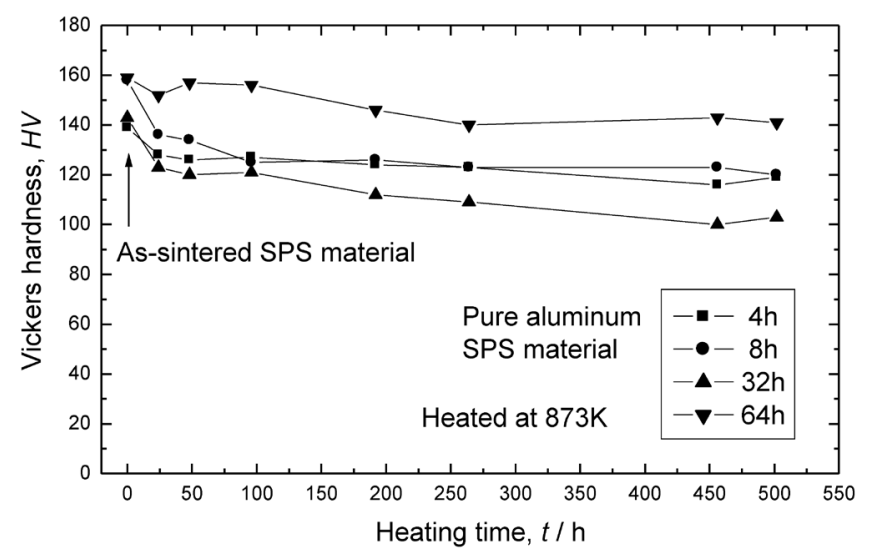

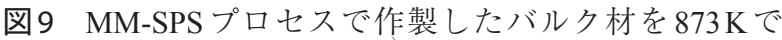
長時間加熱後の硬さ ${ }^{28}$

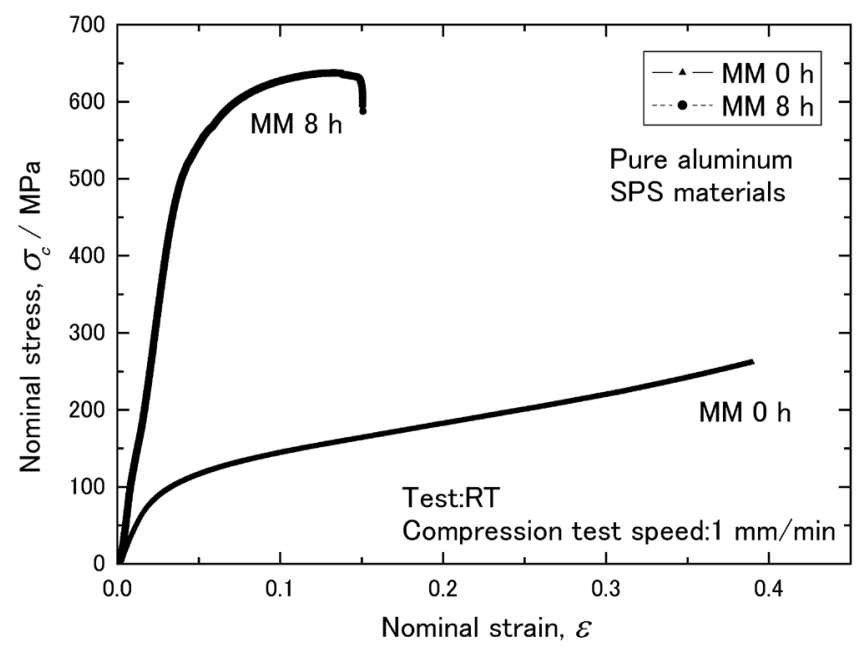

図 10 MM-SPS プロセスで作製したバルク材を室温で 圧縮試験した公称応力と公称ひずみの関係 ${ }^{28}$

て重要なファクターであることが明らかにされている ${ }^{21), 28)}$ これらの結果は, 安価なステアリン酸を伴ったMM-SPS プロ セスによって固相反応を誘起させることで強化相が生成でき ることを示しており, かつ高価な合金元素を添加しない䪊 的な合金設計とプロセス設計の相乗効果が生み出した結果で ある。

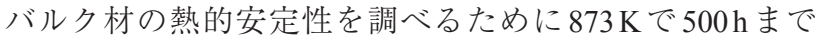
加熱後, 室温で硬さを測定した結果を図 $9^{28)}$ に示す。加熱時 間が $24 \mathrm{~h}$ で各バルク材の硬さは，作製時の硬さと比較して約 $10 \%$ 程度低下した。その後, 加熱時間が $500 \mathrm{~h}$ まで硬さのレ ベルは $100 \mathrm{HV}$ 以上を維持し，優れた熱的安定性を示した。

MM-SPS プロセスの高強度化に対する有効性をさらに検 証するために，MM処理をしていない粉末およびMM $8 \mathrm{~h}$ か ら得られた粉末から作製したバルク材を室温で圧縮試験を 行い, 得られた公称応力一公称ひずみ曲線を図 $10^{28)}$ に示 す。MM処理をしていない粉末から作製したバルク材では $80 \mathrm{MPa}$ 付近から降伏が始まっているが, MM $8 \mathrm{~h}$ の粉末から 作製したバルク材では $500 \mathrm{MPa}$ を超えたあたりから降伏が 認められ, 圧縮強さ $642 \mathrm{MPa}$ を示した。この值は, 高強度 A7075 合金-T6材の引張強さ $525 \mathrm{MPa}^{1)}{ }^{1)}$ をははるかに超える 值である。これらのバルク材の縦弾性係数には明瞭な差が認 


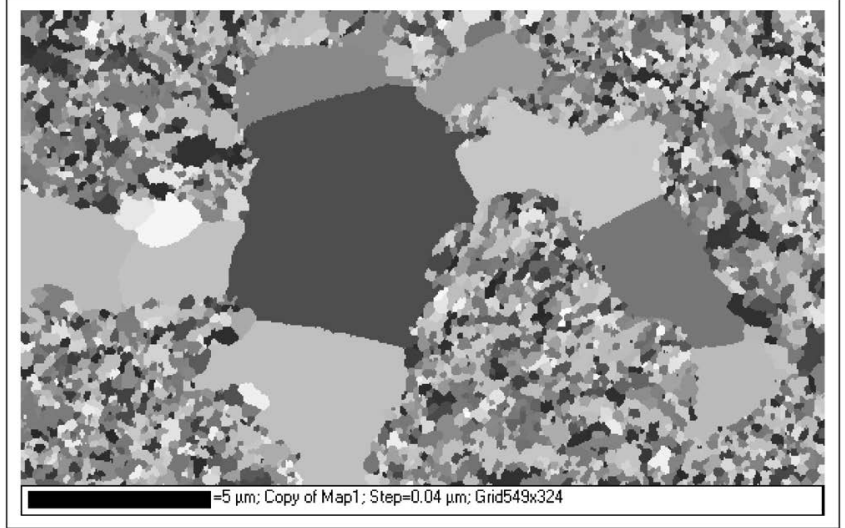

図11 MM 8hの粉末から作製したバルク材のオイラー 方位イメージマップ28)

められており，図 $8^{28)}$ に示されているように固相反応によっ て生成した $\gamma-\mathrm{Al}_{2} \mathrm{O}_{3}$ や $\mathrm{Al}_{4} \mathrm{C}_{3}$ の寄与によって, $\mathrm{MM} 8 \mathrm{~h}$ の粉末 から作製したバルク材ではヤング率が向上したと考えられ る。

MM 8hの粉末から作製したバルク材の組織を SEM-EBSD で解析した結果を図 $11^{18)}$ に示す。平均結晶粒径が2から 5 ミ クロンオーダーの粗大な結晶粒とそれらを取り囲むように 300 ナノオーダーの微細な結晶粒が観察された。このような 特異なバイモーダル組織によって，図 $10^{28)}$ に示したように 高強度と比較的高い延性を兼備した優れた特性を示したと考 えられる。これらの結晶粒は，大傾角粒界を有し，かつ特定 の結晶方位を示す異方性は認められていない。

\section{2 純チタンに対するMM-SPSプロセスの適用（PCA）}

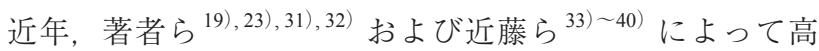
価な合金元素を添加せず，環境負荷の少ない，安価なユビキ タス元素による純チタンの高強度化に関する研究が精力的に 進められている。その中でも著者らは，図6に示したように ユビキタス元素である炭素, 水素, 酸素から構成されるステ アリン酸に着目した合金設計を検討してきた。これらのユビ キタス元素は MM処理に必要不可欠な PCAであり, かつ固 相反応を誘起させる重要な役割を担っている。また，MM処 理によって固相反応を誘起させ化合物相を生成させるだけで なく，過分なユビキタス元素がマトリックス中に固溶するこ とで，複合的な強化によって機械的性質の向上が図られるこ とを明らかにしてきた ${ }^{19)}$,22),31),32)。さらに，ステアリン酸の 添加量を変化させることで MM処理中の潤滑作用に影響を 与え, マトリックス中の固溶量や化合物相の生成量を最適に 制御できる基礎的な知見を見出している $\left.\left.\left.{ }^{19)}, 22\right), 31\right), 32\right) 。$

図 12 および図 13 にステアリン酸をそれぞれ $0.25 \mathrm{~g}$ および $0.50 \mathrm{~g}$ 添加し, $\mathrm{MM}$ 時間を変化させたときの粉末の固相反応 過程を示す。MM処理をしていない粉末からは, $\alpha-\mathrm{Ti}^{41)}$ のみ が同定されたが，ステアリン酸をそれぞれ添加し，各 MM時 間から得られた粉末では， $\alpha-\mathrm{Ti}$ と $\mathrm{TiH}_{2}{ }^{42)}$ が同定された。こ れは，MM処理中にチタン粉末とステアリン酸を構成してい る水素が固相反応したことを示唆している。また，図13よ りステアリン酸を $0.50 \mathrm{~g}$ 添加し, $\mathrm{MM} 8 \mathrm{~h}$ の粉末では $\mathrm{TiN}^{43)}$ も 同定された。これは，空気中の窒素と固相反応したことが推 察される。

ステアリン酸の添加量をパラメータとして各MM時間に

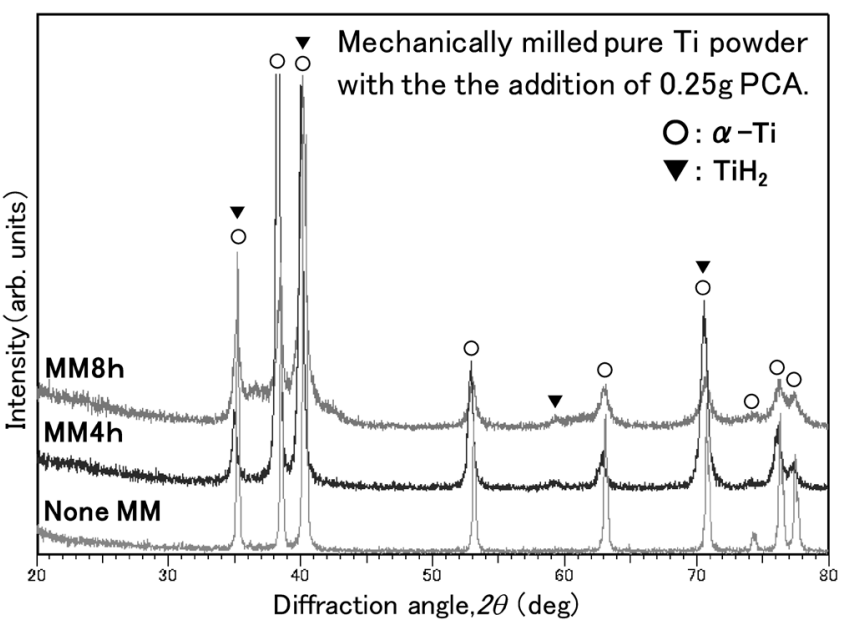

図 12 純チタン粉末にステアリン酸 $0.25 \mathrm{~g}$ を添加して MM 処理して作製した粉末のX線回折パターン ${ }^{19)}$

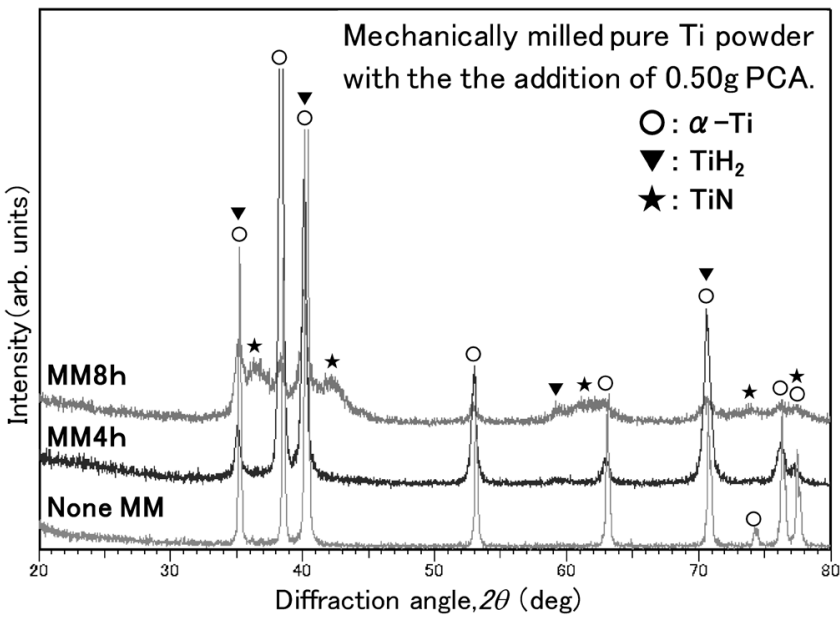

図 13 純チタン粉末にステアリン酸 $0.50 \mathrm{~g}$ を添加して MM 処理して作製した粉末のX線回折パターン ${ }^{19)}$

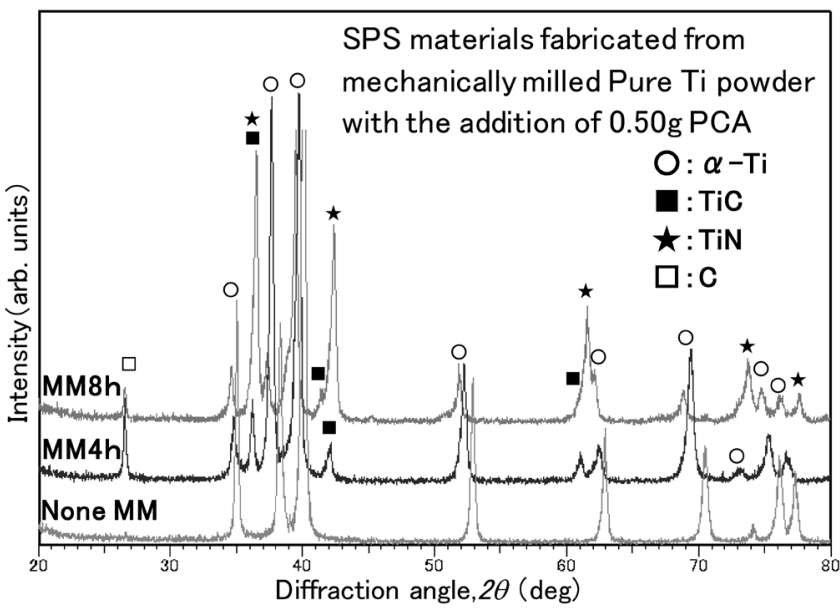

図14 純チタン粉末にステアリン酸 $0.50 \mathrm{~g}$ を添加して MM処理して作製した粉末から得られたバルク 材のX線回折パターン ${ }^{19}$

対する粉末の硬さを測定した結果, MM処理をしていない純 チタン粉末の硬さ $189 \mathrm{HV}$ と比較して，ステアリン酸を $0.25 \mathrm{~g}$ 添加した粉末は, MM時間と共に硬さは増加し MM $8 \mathrm{~h}$ で最 も高い值 $513 \mathrm{HV}$ を示した。ステアリン酸を添加したMM $8 \mathrm{~h}$ 


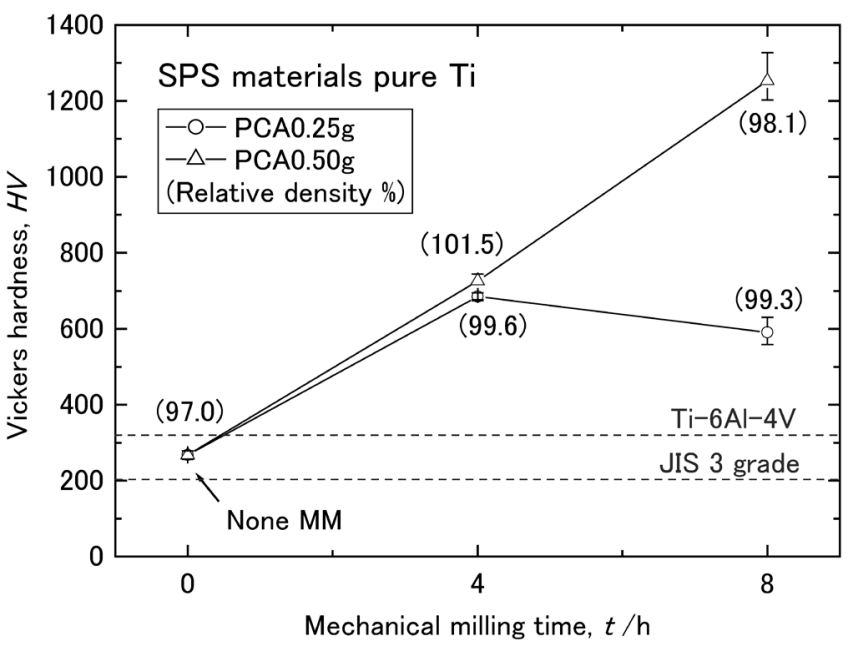

図15 純チタン粉末にステアリン酸を添加してMM処 理して作製した粉末から得られたバルク材の硬

の粉末の硬さは, Ti-6Al-4V 合金よりも高く, ユビキタス化 を構築し，かつ環境負荷を低減させた材料が得られる可能性 が示されている。

図 14 にステアリン酸を $0.50 \mathrm{~g}$ 添加し, 各 $\mathrm{MM}$ 時間によって 得られた粉末から作製したバルク材の化合物相を同定したX 線回折結果を示す。各バルク材では， $\alpha-\mathrm{Ti}$ のかに $\mathrm{TiC}^{44)}$ が 同定された。また, ステアリン酸を $0.25 \mathrm{~g}$ 添加し, MM処理 から作製したバルク材でも $\mathrm{TiC}$ が同定されている。また，ス テアリン酸を $0.50 \mathrm{~g}$ 添加し, MM $8 \mathrm{~h}$ の粉末から作製したバル ク材からは粉末と同様に TiNが同定された。一方, MM処理 された粉末で同定された $\mathrm{TiH}_{2}$ はSPS 中の加熱によって固相 分解 ${ }^{45)}$ したため, バルク材では同定されなかった。

ステアリン酸を $0.25 \mathrm{~g}$ および $0.50 \mathrm{~g}$ 添加し, MM処理した 粉末から作製したバルク材の硬さおよび相対密度の変化を 図15に示す。MM処理をしていない粉末から作製したバル ク材の硬さ $268 \mathrm{HV}$ は, 純チタン JIS 3 種よりも高い值であり, 各条件で作製したすべてのバルク材の硬さは, 純チタン JIS 3 種や Ti-6Al-4V 合金の硬さより上回っている。また, ステ アリン酸を $0.50 \mathrm{~g}$ 添加したバルク材の硬さは, $\mathrm{MM}$ 時間の増 加に伴い高くなり，MM $8 \mathrm{~h}$ で最も高い值 $1253 \mathrm{HV}$ を示した。 これは，図14に示したように固相反応により生成した $\mathrm{TiC}^{44)}$ に加え， $\mathrm{TiN}^{43)}$ による分散強化が複合的に寄与したことが考 えられる。

MM-SPS プロセスで作製したバルク材の相対密度は，いず れの試料も $100 \%$ に近い值が得られている。この結果は, 選 定したSPS焼結条件が適切だったことを示唆している。ま た，固相反応によって生成する金属間化合物の影響によっ て，100\%を越える相対密度を示す試料もあった。

\section{3 純チタンに対するMM-SPS プロセスの適用（雾囲気）}

ユビキタス化による純チタンの高強度化は, PCAから導 入される水素, 炭素, 酸素だけでなく大気中に存在する窒 素からも導入が図られることが明らかとなったことから MM 処理中の雲囲気の違いによる効果を検証した。MM $4 \mathrm{~h}$ ， ス テアリン酸を $0.25 \mathrm{~g}$ 一定として添加し, $\mathrm{MM}$ 処理中の雲囲気 をアルゴンガス（Ar）または大気（Air）とした時に得られ た粉末のX線回折結果を図16に示す。MM処理中の䨌囲気

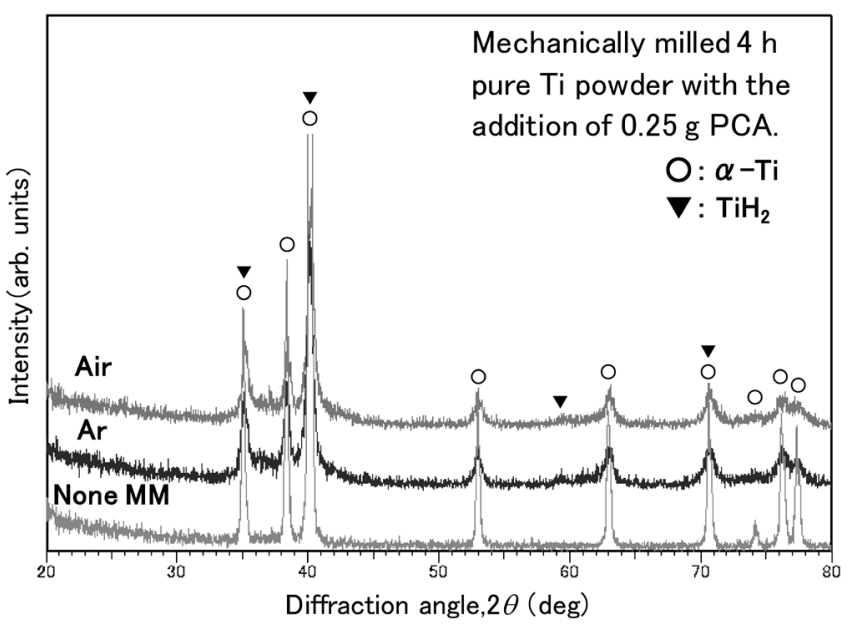

図 16 純チタン粉末にMM 4hステアリン酸 $0.25 \mathrm{~g}$ を添 加して MM処理雲囲気を変化させて作製した粉 末のX線回折パターン 31

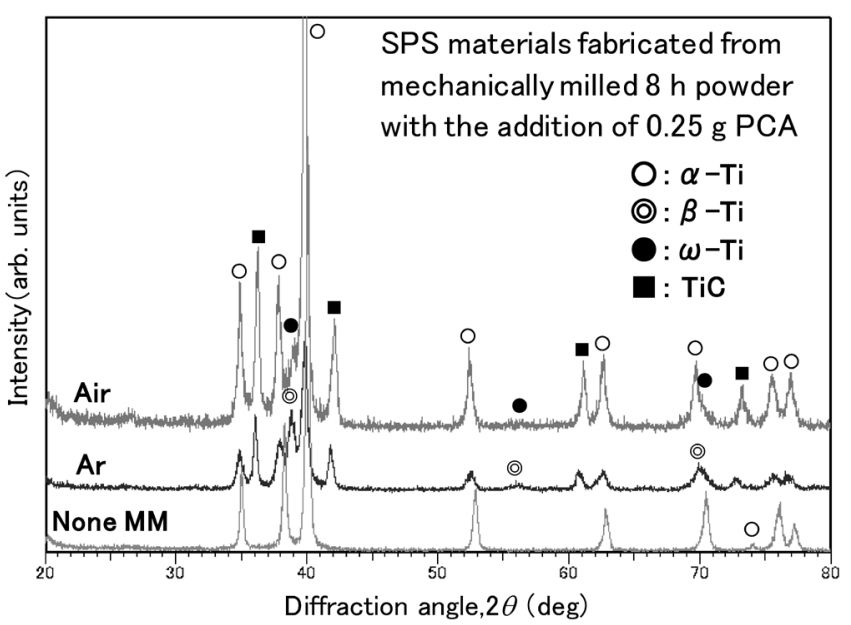

図 17 純チタン粉末にMM $8 \mathrm{~h}$ ステアリン酸 $0.25 \mathrm{~g}$ を添 加してMM処理雲囲気を変化させて作製した粉 末から得られたバルク材のX線回折パターン 31 )

の違いによる構成相に変化は認められず， $\alpha-\mathrm{Ti}^{41)}$ と $\mathrm{TiH}_{2}{ }^{42)}$ が同定された。次に, ステアリン酸の添加量を増加させ Air 雲囲気での MM 処理によって, 炭素や酸素などの供給量を 多くすることで固溶量を増加させる試みを実施したが， $\alpha-\mathrm{Ti}$ の回折ピーク位置が低角度側にシフトするといった変化は認 められなかった。さらに, ステアリン酸を $0.50 \mathrm{~g}$ 添加し, Air 雲囲気一定として MM 時間を変化させたときのX線回折結果 では，MM 4hのとき， $\alpha-\mathrm{Ti}$ と $\mathrm{TiH}_{2}$ が同定されたが，MM $8 \mathrm{~h}$ の粉末では, これらに加え $\mathrm{TiC}^{44)}$ も同定された。 $\mathrm{MM}$ 時間を 長くしても $\alpha$-Ti の回折ピーク位置に変化は認められなかっ た。このことから, MM時間の増加に伴い固相反応は促進さ れるが, ユビキタス元素の固溶量は変化しないことが示唆さ れた。以上のことから, 粉末の構成相の変化には, MM処理 中の雲囲気の違いよりも MM時間の方が支配的なことが明 らかである。

MM $8 \mathrm{~h}$, ステアリン酸を $0.25 \mathrm{~g}$ 一定として添加し, MM 処理中の雲囲気を変化させた粉末から作製したバルク材の X線回折結果を図 17 に示す。Air雲囲気および $\mathrm{Ar}$ 雾囲気 ${ }^{19)}$ の MM処理から作製したバルク材では，ともに $\alpha$-Tiに加え， 
$\mathrm{TiC}$ が同定された。これは, MM処理をしていない粉末か ら作製したバルク材では $\mathrm{TiC}$ が同定されていないことから, $\mathrm{TiC}$ 生成にはステアリン酸を構成している炭素と純チタン がMM処理中に均一に混合され，SPS中の加熱によって固相 反応が誘起されることを示唆している。また, Air 雲囲気で は，それらに加え $\left(\omega-\mathrm{Ti}^{46)}{ }^{47)}\right.$ の生成が認められたが， $\mathrm{Ar}$ 䨌囲

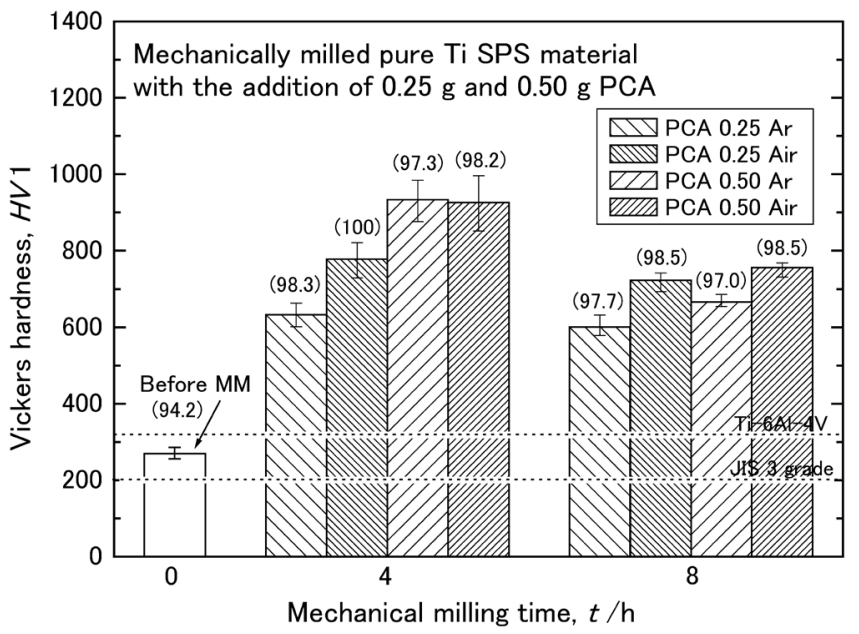

図18 純チタン粉末にステアリン酸量とMM処理雲囲 気を変化させて作製した粉末から得られたバル ク材の硬さ ${ }^{31}$

表 1 各バルク材のユビキタス元素の化学分析組成 ${ }^{31)}$

\begin{tabular}{c|c|c|c|c}
\hline \hline \multirow{2}{*}{ 材料記号 } & \multicolumn{4}{|c}{ 化学組成 (mass \%) } \\
\cline { 2 - 5 } & $\mathrm{H}$ & $\mathrm{C}$ & $\mathrm{N}$ & $\mathrm{O}$ \\
\hline MM 4h 0.25 g Ar & 0.33 & 1.96 & 0.27 & 1.16 \\
MM 4h 0.25 g Air & 0.38 & 1.95 & 0.63 & 1.78 \\
\hline MM 4h 0.50 g Ar & 0.56 & 3.02 & 0.06 & 4.20 \\
MM 4h 0.50g Air & 0.61 & 3.09 & 0.53 & 5.15 \\
\hline MM 8h 0.25 g Ar & 0.35 & 2.02 & 0.07 & 1.04 \\
MM 8h 0.25 g Air & 0.39 & 2.15 & 0.71 & 1.27 \\
\hline MM 8h 0.50g Ar & 0.63 & 3.73 & 0.35 & 1.33 \\
MM 8h 0.50g Air & 0.64 & 3.75 & 0.76 & 1.82 \\
\hline
\end{tabular}

気では, $\beta-\mathrm{Ti}^{48) \sim 50)}$ が生成した。さらに, Air雲囲気で MM 処理した粉末から作製したバルク材では， $\alpha$-Tiの回折ピーク 位置が低角度側にシフトしている。このような現象は, ステ アリン酸を構成する炭素, 水素, 酸素が MM処理中にマト リックス中に均一に分散し, SPS中の加熱によってこれらが 拡散し, 固溶したことを示唆している。しかし, MM処理中 の雲囲気を变化させても $\alpha$-Tiの各結晶面の回折ピーク位置は 変わらなかった。

ステアリン酸の添加量, $\mathrm{MM}$ 時間および $\mathrm{MM}$ 処理中の雲囲 気が異なる粉末から作製したバルク材の硬さと相対密度を 図 18 に示す。MM 4h, ステアリン酸の添加量 $0.50 \mathrm{~g}$ 以外の 条件で, 硬さはAir雲囲気の方が $13 \%$ 以上高い值を示した。 ArおよびAir䨌囲気ともにMM 4h, ステアリン酸の添加量 $0.50 \mathrm{~g}$ で最も高い值，それぞれ $933 \mathrm{HV}$ および $923 \mathrm{HV}$ を示し た。MMプロセスは, 粉末表面に形成している酸化被膜を微 細に粉砕し, それらの酸化物粒子をマトリックス中に均一に 分散させることが可能である。したがって, 純チタン粉末を Air雲囲気でMM処理することによって, 粉末が破砕される とき，粉末表面には新たな $\mathrm{TiO}_{2}$ が繰り返し生成し， $\mathrm{TiO}_{2}$ 粒 子の体積分率の増加とそれらの分散によって強化されたと推 察した。吉村らは， $\mathrm{TiO}_{2}$ 粒子の分散による強化作用は結晶粒

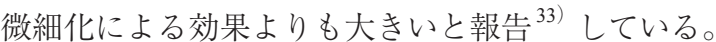

各条件で作製したバルク材に含まれるユビキタス元素を定 量的に分析した結果を表 1 に示す。Ar雾囲気と比較して Air 雾囲気でMM処理することにより, 窒素量および酸素量が顕 著に増加している。この結果は, これらの元素がMM処理 中にAirから供給されたことを示唆しており，ユビキタス元 素を利用した合金設計の有効性が示されている。また，表 2 に示すように添加するステアリン酸の各ユビキタス元素の理 論值と表 1 に示したバルク材に含まれるユビキタス元素の化 学分析值を比較すると, 水素量および炭素量は, ほぼ同程度 の值を示した。したがって，これらのユビキタス元素はステ アリン酸から供給されたことを示唆している。一方, 窒素量 および酸素量は，ステアリン酸の添加量から求めた理論值よ りも化学分析值の方が多く含有していることから, Airから 供給されている可能性が示唆された。以上の結果から, PCA の添加量と $\mathrm{MM}$ 処理中の雲囲気を適切に組み合わせれば，バ ルク材に含まれるユビキタス元素の量を制御できる可能性が 示された。すなわち, 要求されるバルク材の機械的性質は,

表2 $\mathrm{MM}$ 処理時に添加したステアリン酸中に含まれるユビキタス元素の理論值 ${ }^{31}$

\begin{tabular}{|c|c|c|c|}
\hline $\begin{array}{c}\text { メカニカルミリング時間 } \\
(\mathrm{h})\end{array}$ & $\begin{array}{l}\text { ステアリン酸量 }(\mathrm{g}) \\
\text { と組成 }(\operatorname{mass} \%)\end{array}$ & メカニカルミリング雲囲気 & 材料記号 \\
\hline \multirow{2}{*}{4} & $\begin{array}{c}0.25 \\
(\mathrm{H}: 0.32, \mathrm{C}: 1.90, \mathrm{O}: 0.28)\end{array}$ & $\begin{array}{l}\text { Ar } \\
\text { Air }\end{array}$ & $\begin{array}{l}\text { MM 4h } 0.25 \mathrm{~g} \mathrm{Ar} \\
\text { MM 4h } 0.25 \mathrm{~g} \mathrm{Air}\end{array}$ \\
\hline & $\begin{array}{c}0.50 \\
(\mathrm{H}: 0.64, \mathrm{C}: 3.80, \mathrm{O}: 0.56)\end{array}$ & $\begin{array}{l}\text { Ar } \\
\text { Air }\end{array}$ & $\begin{array}{l}\text { MM 4h } 0.50 \mathrm{~g} \mathrm{Ar} \\
\text { MM 4h 0.50g Air }\end{array}$ \\
\hline \multirow{2}{*}{8} & $\begin{array}{c}0.25 \\
(\mathrm{H}: 0.32, \mathrm{C}: 1.90, \mathrm{O}: 0.28)\end{array}$ & $\begin{array}{l}\text { Ar } \\
\text { Air }\end{array}$ & $\begin{array}{l}\text { MM } 8 \mathrm{~h} 0.25 \mathrm{~g} \mathrm{Ar} \\
\text { MM } 8 \mathrm{~h} 0.25 \mathrm{~g} \mathrm{Air}\end{array}$ \\
\hline & $\begin{array}{c}0.5 \\
(\mathrm{H}: 0.64, \mathrm{C}: 3.80, \mathrm{O}: 0.56)\end{array}$ & $\begin{array}{l}\text { Ar } \\
\text { Air }\end{array}$ & $\begin{array}{l}\text { MM } 8 \mathrm{~h} 0.50 \mathrm{~g} \mathrm{Ar} \\
\text { MM } 8 \mathrm{~h} 0.50 \mathrm{~g} \mathrm{Air}\end{array}$ \\
\hline
\end{tabular}

※ Experimentally used pure Ti (H:0.016, C:0.009, O:0.31) 
これらの2つのパラメータを適切にコントロールすることに よって導き出される。

\section{4. おわりに}

本解説では，高価な合金元素を添加せずに純アルミニウム または純チタンの機械的性質を飛躍的に向上させる手法に関 してプロセス設計および合金設計の概念を紹介した。特にユ ビキタス化とリサイクル推進の観点から PCAとして添加す るステアリン酸を利用したMM-SPS プロセスを新たに構築 し，これらの革新的なプロセスから作製された純アルミニウ ムと純チタンの特性を概説した。

純アルミニウムでは，固相反応によって $\mathrm{Al}_{4} \mathrm{C}_{3} や \gamma-\mathrm{Al}_{2} \mathrm{O}_{3}$ が 生成し, これらの化合物粒子による分散強化や結晶粒のバイ モーダル化によって， MM処理をしていない粉末から作製し たバルク材，すなわち $\mathrm{Al}_{4} \mathrm{C}_{3} や \gamma-\mathrm{Al}_{2} \mathrm{O}_{3}$ を含まない材料と比較 して硬さで約 4 倍, 圧縮強度で約 6 倍の特性が導き出される ことに成功した。また，特に $873 \mathrm{~K}$ の加熱に対しても極端な 硬さの低下は認められず，優れた熱的安定性を示したことは 特筆すべき点である。

純チタンでは，機械的性質を高める基となるユビキタス元 素の水素拉よび炭素はステアリン酸から供給され，窒素お よび酸素はAir雲囲気から供給できることを明らかにした。 PCAの添加量と MM 処理中の雲囲気を適切に選択すれば, ユビキタス元素量を制御することが可能であり，これによっ てバルク材の機械的性質を容易に制御でき，硬さに関しては $13 \%$ 以上向上させることに成功した。

軽金属に対する革新的な PCAを伴ったMM-SPS プロセス の適用は，図 2 に示した材料の強化機構が加算的に寄与する ことによって，レアメタルなどの高価な合金元素を用いずに 純アルミニウムおよび純チタンの高強度化が達成できること を実証した。

\section{謝 辞}

本研究の一部は, 公益財団法人軽金属奨学会教育研究資金 を基に行われました。特記して深く感謝の意を表す。純アル ミニウム粉末は, 東洋アルミニウム株式会社のご厚意により 提供されました。関係各位に感謝申し上げます。

\section{参 考 文 献}

1) 40 周年記念事業実行委員会：アルミニウムの組織と性質，軽金 属学会, (1991)

2) 軽金属協会標準化総合委員会：アルミニウムハンドブック（第 6版), 軽金属協会, (2001).

3) R. M. German：粉末治金の科学, 三浦秀士・高木研一 共訳, 内田老鶴圃, (1996).

4) 渡辺侊尚：粉末治金，技術書院，（1997）.

5）新家光雄，塙 隆夫，池田勝彦，千葉晶彦，古原 忠，成島尚 之, 土谷浩一, 江村 聡, 中野貴由, 竹中俊英：日本金属学会 誌, 72 (2008)，915

6) 新家光雄 : 第 61 回白石記念講座 ユビキタス時代に向けたチ 夕ンの元素戦略と新しい用途展開, 日本鉄鋼協会, (2009), $1-15$.

7) 新家光雄：日本金属学会誌，75（2011），21-28,
8) J. S. Benjamin: Metall. Trans., 1 (1970), 2943-2951.

9）堀内 良, 小原嗣朗：軽金属, 32（1982），688-695.

10）渡辺龍三：日本金属学会会報，27（1988），799-801。

11）小原嗣朗：軽金属, 40（1990），703-711。

12）新宮秀夫：軽金属, 40 (1990)，850-855

13) C. Suryanarayana: Prog. Mater. Sci., 46 (2001), 1-184.

14）粉体工学会：紛体粒子の組織制御による機能付与, 日刊工業新 聞社, (2008).

15）金子純一：軽金属，53（2003）, 601-614.

16）铇田正雄：粉体工学会誌, 30（1993）, 790-804.

17) 大森 守：まてりあ, 39 (2000), 54-57.

18) M. Kubota and B. P. Wynne: Scr. Mater., 57 (2007), 719-722.

19）大野卓哉, 久保田正広：軽金属，59（2009），659-665。

20) M. Kubota: J. Alloys Compd., 434-435 (2007), 294-297.

21）久保田正広：軽金属, 62（2012），419-423.

22) 大野卓哉, 久保田正広：粉体および粉末治金, 57 (2010), 327-332.

23) Y. F. Zhang, L. Lu and S. M. Yap: J. Mater. Process. Technol., 89-90 (1999), 260-265.

24）仙名 保：日本金属学会会報，27（1988），802-804.

25）金 得圭, 金子純一, 菅又 信：日本金属学会誌, 57 (1993), 679-685.

26）金 得圭, 金子純一, 菅又 信：日本金属学会誌，57（1993）, 1325-1332.

27）山崎晃弘，金子純一，菅又 信：軽金属, 52（2002）, 421-425.

28）久保田正広：軽金属, 62 (2012), 424-428.

29) PDF: 10-0425, $\gamma-\mathrm{Al}_{2} \mathrm{O}_{3}$, International Centre for Diffraction Data, (1999).

30) PDF: 35-0799, $\mathrm{Al}_{4} \mathrm{C}_{3}$, International Centre for Diffraction Data, (1999).

31）大野卓哉, 久保田正広：軽金属, 60 (2010), 647-653.

32) 大野卓哉, 久保田正広：日本機械学会論文集 (A 編), 77 (2011), 26-30.

33) 吉村知浩, 今井久志, 近藤勝義：日本金属学会誌, 73 (2009), 768-772.

34) T. Yoshimura, H. Imai, T. Threrujirapapong and K. Kondoh: Mater. Trans., 50 (2009), 2751-2756.

35) T. Yoshimura, T. Threrujirapapong, H. Imai and K. Kondoh: Mater. Sci. Forum, 654-656 (2010), 815-818.

36) 孫 斌, 李 樹豊, 今井久志, 三本嵩哲, 梅田純子, 近藤勝義 スマートプロセス学会誌, 1 (2012)，283-287.

37) B. Sun, S. Li, H. Imai, T. Mimoto, J. Umeda and K. Kondoh: Mater. Sci. Eng. A, 563 (2013), 95-100

38) 三本嵪哲, 李 樹豊, 梅田純子, 近藤勝義：粉体および粉末治 金, 60 (2013), 467-474.

39) K. Kondoh, B. Sun, S. Li, H. Imai and J. Umeda: Int. J. Powder Metall., 50 (2014), 35-40.

40) T. Mimoto, J. Umeda and K. Kondoh: Powder Metall., 59 (2016), 223-228.

41) JCPDS: 44-1294, $\alpha$-Ti, International Centre for Diffraction Data, (1999).

42) JCPDS: 03-0859, $\mathrm{TiH}_{2}$, International Centre for Diffraction Data, (1999).

43) JCPDS: 38-1420, TiN, International Centre for Diffraction Data, (1999).

44) JCPDS: 32-1383, TiC, International Centre for Diffraction Data, (1999).

45）小橋 眞，棚橋伸也，金武直幸：軽金属，53（2003），427-432。

46) JCPDS: $71-3947, \omega$-Ti, International Centre for Diffraction Data, (1999).

47) Y. Todaka, J. Sasaki, T. Moto and M. Umemoto: Scr. Mater., 59 (2008), 615-618.

48) JCPDS: 44-1288, $\beta$-Ti, International Centre for Diffraction Data, (1999).

49) T. Tsuchiyama, S. Hamamoto, K. Nakashima and S. Takaki: Mater. Sci. Eng. A, 474 (2008), 120-127.

50) T. B. Massalski: Binary Alloy Phase Diagrams, American Society For Metals, First Printing, (1986), 595, 1118, 1284, 1793. 